Kabir et al., 2010

Stamford Journal of

Pharmaceutical Sciences

S. J. Pharm. Sci. 3(1): 34-37

\title{
Formulation Development of Verapamil Hydrochloride Tablet by Effervescent Method
}

\author{
*Abul Kalam Lutful Kabir ${ }^{1}$, Naz Hasan Huda², Yeakuty Marzan Jhanker ${ }^{3}$ \\ and Kamrunnahar Sharmin ${ }^{2}$ \\ ${ }^{1}$ Department of Pharmacy, Jagannath University, Dhaka, Bangladesh. \\ ${ }^{2}$ Department of Pharmacy, Stamford University Bangladesh, \\ Dhaka, Bangladesh. \\ ${ }^{3}$ Department of Pharmacy, The University of Asia Pacific Dhaka, Bangladesh.
}

\author{
*Corresponding Author: \\ Abul Kalam Lutful Kabir \\ Lecturer, Dept. of Pharmacy \\ Jagannath University \\ Dhaka-1100, Bangladesh. \\ Contact No.: +8801920764100 \\ E-mail: Ikabir81@yahoo.com
}

\begin{abstract}
Fast disintegrating tablets of Verapamil Hydrochloride were designed to achieve increased absorption as well as quick onset of pharmacological action of the active ingredient with a view to enhance patient compliance by effervescent method. Different combinations and ratios of sodium bicarbonate, anhydrous citric acid, sodium starch glycolate, Micro-crystalline cellulose (MCC) and lactose were used in order to get optimum result. The prepared formulations were evaluated for hardness, friability, thickness, diameter, taste of the solution to be administered and in-vitro dispersion time. The acceptable dispersion time was achieved by using a combination of citric acid and sodium bi carbonate in the same amount along with sodium starch glycolate, micro-crystalline cellulose (MCC) \& lactose. Acceptable taste of the solution to be administered was obtained with a combination of sucrose, aspartame and sodium saccharine.
\end{abstract}

Key words: Effervescent method, Verapamil Hydrochloride, Dispersion time.

\section{INTRODUCTION}

Verapamil hydrochloride (VPH) is a calcium channel blocker used in the control of supraventricular arrhythmia, hypertension and myocardial infarction. It is an ion influx inhibitor (slowchannel blocker or calcium ion antagonist) available for oral administration in film-coated tablet forms containing $40 \mathrm{mg}, 80 \mathrm{mg}$ or $120 \mathrm{mg}$ of verapamil hydrochloride (Hoffman, 2006). VPH exerts its pharmacological effects by modulating the influx of ionic calcium across the cell membrane of the arterial smooth muscle as well as in conductile and contractile myocardial cells. It is mainly used in the treatment of angina (to ease coronary artery spasm), arrhythmia (to slow down atrioventricular conduction) and hypertension (to reduce systemic vascular resistance) (Trevor et al., 2002).

As per revised definition proposed to US FDA, Effervescent tablet is a tablet intended to be dissolved or dispersed in water before administration. In addition to active ingredients, it generally contains mixture of acids/acid salts and carbonate and hydrogen carbonates which release carbon dioxide when mixed with water (Parikh, 2005). Effervescence is the evolution of gas bubbles from a liquid, as the result of a chemical reaction. The most common reaction for pharmaceutical purpose is the acid base reaction between sodium bicarbonate and citric acid (Rowe et al., 2009).

$$
3 \mathrm{NaHCO}_{3}+\mathrm{C}_{6} \mathrm{H}_{8} \mathrm{O}_{7}+\mathrm{H}_{2} \mathrm{O} \rightarrow \mathrm{C}_{6} \mathrm{H}_{5} \mathrm{O}_{7}+4 \mathrm{H}_{2} \mathrm{O}+\mathrm{CO}_{2} \uparrow
$$

This reaction starts in presence of water, even with small amount as catalyzing agent, and because water is one of the reaction products, it accelerates the rate of reaction, leading to difficulty in stopping the reaction. For this reason, the whole manufacturing and storage of effervescent products is planned by minimizing the contact with water (Martindale: The Complete Drug Reference, 2009).

Aim of the current work was to design fast disintegrating tablet of Verapamil Hydrochloride to attain higher and quicker absorption of the active ingredient in order to enhance patient compliance. 


\section{MATERIALS}

Verapamil Hydrochloride was a gift sample from Incepta Pharmaceuticals Limited, Bangladesh. Sodium bi-carbonate was purchased from Techno Pharmaceuticals, India. Sodium saccharine, Citric acid, Talc and Sucrose were obtained from Merck KGaA, Germany. Povidone K30, Magnesium stearate, Lactose, Sodium starch glycolate, Aerosil and Orange flavor were bought from BASF, India. Micro-crystalline cellulose PH101 and Aspartame were acquired from Gujrat Pharmaceuticals, India. Di calcium hydrogen phosphate was purchased from Loba, India.

\section{METHODS}

Six batches of Verapamil Hydrochloride effervescent tablets (10 tablets per batch) with different formulations were produced by direct compression method. Total weight of each tablet was 350 mg. After formulating each batch, the dispersion time, taste of the liquid solution to be administered and hardness of the tablets were studied.

\section{Preparation of the effervescent tablets}

All the materials used in the formulation were weighted out by using an electronic balance. Sodium bi carbonate and Citric acid were preheated to make them moisture free and this increase compressibility of the Sodium bi carbonate. Then Sodium bi carbonate and Citric acid were crushed by mortar and pastel. Other ingredients were mixed up with the crushed powder of Sodium bi carbonate and citric acid. After mixing, the powder was sieved through a mesh. Finally the powder was compressed with 5 TON compression pressure by using a manually operated single punch tablet compression machine.

\section{Dispersion Time study}

Dispersion Time is the time that a tablet takes to fully disperse into a dispersion medium or a liquid. For an effervescent tablet the dispersion time is about $1 \mathrm{~min}$ to $4 \mathrm{~min}$.

First $250 \mathrm{~mL}$ water was taken in a beaker. A stop watch was set to take the correct reading. One tablet was dropped into the water taken in a $250 \mathrm{~mL}$ beaker. The dispersion time of that tablet was taken. This procedure was repeated for three times and these dispersion times were noted. Finally the average dispersion time was taken (Saleh et al., 1988; Wells et al., 1997).

Table 1: Composition of various tablet formulations.

\begin{tabular}{lllllll}
\hline Materials & F-1 & F-2 & F-3 & F-4 & F-5 & F-6 \\
\hline Verapamil Hydrochloride (VPH) & $80 \mathrm{mg}$ & $80 \mathrm{mg}$ & $80 \mathrm{mg}$ & $80 \mathrm{mg}$ & $80 \mathrm{mg}$ & $80 \mathrm{mg}$ \\
Citric acid & $45 \mathrm{mg}$ & $42 \mathrm{mg}$ & $42 \mathrm{mg}$ & --- & --- & $60 \mathrm{mg}$ \\
Tartaric acid & --- & --- & --- & $42 \mathrm{mg}$ & $50 \mathrm{mg}$ & --- \\
Sodium bi carbonate & $15 \mathrm{mg}$ & $42 \mathrm{mg}$ & $50 \mathrm{mg}$ & $50 \mathrm{mg}$ & $50 \mathrm{mg}$ & $60 \mathrm{mg}$ \\
Povidone K 30 & $9 \mathrm{mg}$ & $3.5 \mathrm{mg}$ & $4 \mathrm{mg}$ & $4 \mathrm{mg}$ & $4 \mathrm{mg}$ & $3 \mathrm{mg}$ \\
Sucrose & $40 \mathrm{mg}$ & $60 \mathrm{mg}$ & $60 \mathrm{mg}$ & $80 \mathrm{mg}$ & $80 \mathrm{mg}$ & $60 \mathrm{mg}$ \\
Aspartame & --- & --- & --- & --- & --- & $15 \mathrm{mg}$ \\
Sodium saccharine & --- & --- & --- & --- & --- & $10 \mathrm{mg}$ \\
Talc & --- & --- & --- & --- & --- & $5 \mathrm{mg}$ \\
Magnesium stearate & $9 \mathrm{mg}$ & $3.5 \mathrm{mg}$ & $2 \mathrm{mg}$ & $2 \mathrm{mg}$ & $2 \mathrm{mg}$ & $2 \mathrm{mg}$ \\
Orange Flavor & --- & --- & --- & --- & --- & $5 \mathrm{mg}$ \\
Micro-crystalline cellulose PH 101 & $12 \mathrm{mg}$ & $12 \mathrm{mg}$ & $12 \mathrm{mg}$ & $12 \mathrm{mg}$ & $12 \mathrm{mg}$ & $15 \mathrm{mg}$ \\
Sodium starch glycolate & --- & --- & --- & $75 \mathrm{mg}$ & $40 \mathrm{mg}$ & $20 \mathrm{mg}$ \\
Lactose & --- & --- & --- & --- & $27 \mathrm{mg}$ & $10 \mathrm{mg}$ \\
Aerosil & --- & --- & $5 \mathrm{mg}$ & $5 \mathrm{mg}$ & $5 \mathrm{mg}$ & $5 \mathrm{mg}$ \\
Di calcium hydrogen phosphate & $140 \mathrm{mg}$ & $107 \mathrm{mg}$ & --- & --- & --- & ---
\end{tabular}


Kabir et al., 2010

RESULTS AND DISCUSSION

Table 2: Hardness and dispersion time of tablets of various formulations

\begin{tabular}{ccccccc}
\hline \multirow{2}{*}{ Properties } & \multicolumn{5}{c}{ Formulations } \\
\cline { 2 - 7 } & F-1 & F-2 & F-3 & F-4 & F-5 & F-6 \\
\hline Average Hardness & $6.63 \mathrm{~kg} / \mathrm{cm}^{2}$ & $8 \mathrm{~kg} / \mathrm{cm}^{2}$ & $3 \mathrm{~kg} / \mathrm{cm}^{2}$ & $6.8 \mathrm{~kg} / \mathrm{cm}^{2}$ & $8 \mathrm{~kg} / \mathrm{cm}^{2}$ & $5.5 \mathrm{~kg} / \mathrm{cm}^{2}$ \\
$\begin{array}{c}\text { Average Dispersion } \\
\text { Time }\end{array}$ & $13 \mathrm{~min}$ & $3 \mathrm{~min}$ & $46 \mathrm{sec}$ & $2 \mathrm{~min}$ & $2 \mathrm{~min}$ & $2 \mathrm{~min}$ \\
\hline
\end{tabular}

In formulation 1, citric acid and sodium bi carbonate were used in a ratio of 3:1. This proportion of citric acid and sodium bi carbonate were not sufficient to produce a quick effervescent reaction which is evident from prolonged dispersion time. Higher proportions of some excipients like dicalcium hydrogen phosphate (diluent), povidone K30 (binder) and magnesium stearate (lubricant) may have lengthened the dispersion time. Again $40 \mathrm{mg}$ sucrose per tablet was not sufficient to musk the unpalatable bitter taste of the solution produced when dispersed in water.

Purpose of formulation 2 was to improve the dispersion characteristics of the tablets as well as to reduce the dispersion time. Here citric acid and sodium bi carbonate were used in the same ratio. This change has shown an improved dispersion characteristic. The proportion of povidon K30 (binder) and magnesium stearate (lubricant) was reduced that may have also improved the dispersion time. It is to be mentioned that during compression of the powder mixture, the hygroscopic characteristics of citric acid caused it to become moist within few minutes even at the room temperature.

In formulation 3 Aerosil was used to reduce the moisture retention problem of the mixture. It helped to reduce the problem to some extent. Amount of sodium bi carbonate was increased slightly more than the amount of the citric acid. This may also have improved the dispersion time. Maize starch was used as diluent which is cheaper than di-calcium hydrogen phosphate. It also markedly improved the dispersion time. However, hardness of the tablet was reduced significantly and it failed to comply with the friability test.

In formulation 4, tartaric acid was used instead of citric acid along with aerosil to solve the moisture absorption problem of citric acid. To keep the dispersion time within 2 minutes, sodium starch glycolate was used as super-disintegrant although the resulting dispersion time was not within the expected range. To reduce the bitterness of the solution to be administered produced after dispersing the tablet into the water, $80 \mathrm{mg}$ sucrose per tablet was used. However, the unpalatable taste was not masked even after using quite high amount of sucrose which suggested that sucrose only is not sufficient enough to mask the bitterness of VPH.

In formulation 5, same amounts of sodium bi carbonate and tartaric acid were used to improve the dispersion time. Amount of sodium starch glycolate was reduced and compensated with lactose. But dispersion time was not improved at all. This batch still had the problem of bitterness of the solution to be administered produced after dispersing the tablet into the water.

Aspartame and sodium saccharine were used along with sucrose in formulation 6 to resolve the bitterness problem of the solution to be administered. Orange flavor was used to increase its acceptability. In this formulation, tartaric acid was replaced by citric acid again because the former excipient produced extreme tart taste which is unpalatable to some extent. Anhydrous citric acid and aerosil were also used to solve the moisture retention problem. Amount of sodium bi carbonate and citric acid were increased but used in the same proportion. To increase the flow property talc and magnesium stearate were also used. Finally the dispersion time came within the expected range means within 2 minutes. Taste of the solution to be administered was acceptable. The hardness of the tablets was also within the limit and the tablets passed the friability test successfully. 


\section{CONCLUSION}

Effervescence has proved its utility as an oral drug delivery system in the pharmaceutical and dietary industries for decades. Effervescent dosage forms are widespread and their use is growing in the whole world because they offer pharmaceutical companies a way to extend their market share. From a drug delivery perspective, there are a number of advantages to effervescent tablets of verapamil hydrochloride. One of the biggest advantages is that they deliver drugs to the body rapidly. Angina or arrhythmia patients who have trouble swallowing pills often appreciate medicine made available in the form of effervescent tablets, as it is usually easy to swallow the solution (Roscheisen et al., 1995). For those patients who are experiencing nausea, the verapamil hydrochloride effervescent tablets can help to settle the stomach and the rapid absorption means that even if the patient vomits, some of the drugs will still have reached the body. Finally we can say that, the effervescent tablets of verapamil hydrochloride were prepared in order to achieve quick on set of pharmacological action of the active ingredient because the drug is delivered in the form of a solution which is easy to absorb (Rotthauser et al., 1998).

\section{ACKNOWLEDGMENT}

With great respect and honor, I am most fortunate and deeply indebted to Professor Dr. A.S.S. Rouf, for his insensate encouragement and support throughout the program of this work. With pleasure I express my sincere gratitude to Professor Dr. Abdul Ghani, Chairman, Department of Pharmacy, Stamford University Bangladesh for his keen interest and for providing lab facilities to carry out this work.

\section{REFERENCES}

Hoffman BB (2006) In - Goodman \& Gilman's - The Pharmacological basis of Therapeutics, 11th Edition, McGraw-Hill Medical Publishing Division, Digital Edition, Chapter 32 - Therapy of Hypertension.

Martindale: The Complete Drug Reference 36, CD-ROM by Sean Sweetman (CD-ROM - Mar 16, 2009).

Roscheisen G, Schmidt PC (1995) Preparation and optimization of L-leucine as lubricant for effervescent tablet formulations, Pharma. Acta Helv, 70 (2):133-139.

Rotthauser B, Kraus G, Schmidt PC (1998) Optimization of an effervescent tablet formulation using a central composite design, Eur. J. of Pharm and Biopharm., 46 (1):85-94.

Rowe RC, Sheskey PJ, Quinn ME (2009). "Handbook of Pharmaceutical Excipients", Sixth Edition, Pharmaceutical Press, London, pp. 181-183.

Saleh SI, Boymond C, Stamm A (1988) Preparation of direct compressible effervescent components: spray-dried sodium bicarbonate; Int. J. Pharm., 45 (1):19-26.

Trevor AJ, Katzung BG, Masters SB (2002) Katzung \& Trevor's Pharmacology: Examination \& Board Review, 6th edition., Lange Medical Books/McGraw-Hill Medical Publishing Division. Pp.109-142.

Wells ML, Wod DL, Santleben R (1997) Potassium carbonate as a desiccant in effervescent tablets, Int. J. Pharm., 152 (2): 227- 235. 